Maciej Nyka, Ph.D. Adiunct, Doctoris iuris, Department of Public Economic Law and Environmental Protection Law, Faculty of Law and Administration, University of Gdansk,

Gdansk, Poland

\title{
LEGAL PREREQUISITES OF THE MANAGEMENT OF NATURAL RESOURCES OF THE MOON AND OTHER CELESTIAL BODIES
}

The main aim of the article is to analyse the existing international legal framework of performing mining activities in the outer space. Exploitation and sharing of natural resources of the outer space is an important challenge for international governance systems. The existing acts of law concerning the utilization of space are outdated and some of them have marginal importance due to the law ratification number. The rules for the use and equitable sharing of benefits coming from the exploitation of natural resources in space can be reconstructed from general principles of law referring to the outer space management as well as in some extent from the international agreements. The principle of non-appropriation, as well as the principle of freedom of conducting scientific research of outer space, formulates borders which embrace the commercial activities in space. The imprecise character of legal principles together with the sometimes ambiguous wording of international legal rules leaves space for discussion as to the character of limits and conditions of space mining activities. Two concepts - the common province of mankind and the common heritage of mankind are engaged to describe the current status of celestial bodies and outer space. Under certain conditions, they can also be treated as describing the status of natural resources of the outer space. The normative consequences of using those two concepts are however unclear. First of those concepts - the common province of mankind - is seldomly used and barely cleared in international legal order. Common heritage of mankind is a well known concept and could substitute for more detailed regulation but also requires certain procedural and institutional framework. The article tries to answer questions concerning the limits of non-appropriation principle, and potential conditions under which space mining activities could be performed "for the benefit of mankind". It also tries to decide if the current system of governance of space, including celestial bodies and natural resources situated on them is sufficient to ensure the promotion of values which stem from principles of international space law. Finally, article tries to predict the prospects of future development of international space law in the field of regulation of natural resources exploitation. By using the analogy from the deep sea mining regime, and basing on the wording of existing sources of international space law, the article indicates areas and directions of probable changes in the international space law.

Keywords: moon, management, norms, law, resources.

Introduction. The management of natural resources in space becomes one of the main challenges of contemporary space law. This is a consequence of many factors among which most important are the rising level of exploitation of Earth's natural resources and the rising demand for natural resources of Asian economies and finally rising technical capability of exploitation of natural resources in space. It is also worth to mention that exploration and exploitation of the cosmic space is not anymore the domain reserved for states. The number of private entrepreneurs acting in the space sector is raising the same as the size of the undertakings they perform in space, substituting national space agencies in some of their duties.

New possibilities connected with the exploitation of space resources rise numbers of questions both of philosophical/ethical as well as legal nature. It seems that there exists a consensus not to allow for unsustainable space resources management what brought our contemporary civilisation at the edge. Contemporary civilisation struggle both with high demand for resources needed for industrial processes as well as with severe adverse effects of such processes like pollution, and other social problems. There is a need to apply new natural resources management methodologies and tools (including legal framework). 
Common requirement often mentioned in case of natural resources management is an expectation that such resources should be shared in an equitable way. Application of equity which is often understood as a practical aspect of justice [1,2], requires the balancing of various interests of states, international organisations, societies and individuals. The process of balancing has to be performed while distributing advantages (but also burdens) connected with the exploitation of natural resources of the outer space [3]. The distributive justice in sharing the natural resources of Moon and other celestial bodies manifests itself in fair, reliable, competent and carried out by eligible entities, distribution of benefits and burdens between countries, other subjects of international law [1], societies and even generations [3]. The space law has to face various practical problems connected with good governance in the management of the outer space and its resources. Emphasise, similarly as it is in the deep sea mining regime, should be put on the finding equilibrium between outer space resources exploitation and the protection of environment [4].

Beyond any doubt, the exploration and exploitation of natural resources of outer space give humanity a sort of second chance. In order not to spoil this opportunity there is a need for complex, procedural and material legal architecture supported by political consensus. This construction has to be based on values like justice, security and sustainability [5]. The already existing legal institutions, like "province of mankind" or "common heritage of mankind" apply to the outer space regime with all weaknesses and strengths which can be observed in Arctic Treaty or United Nations Convention on the Law of the Sea [6, 7]. This brings upon a question whether new instruments of managing areas beyond national jurisdiction in space should not be introduced in order to support the achievement of desired values.

The main aim of the article is to analyse the existing international legal framework of performing mining activities in the outer space.

Results. Moon and other celestial bodies, including asteroids contain lots of minerals vital for our resource-based economy [8]. The crust of the Moon's surface contains numerous raw materials such as aluminium, titanium, manganese, not to speak of more commonly occurring on Earth such as iron, coal, nitrogen, magnesium, silicon, and even oxygen or water. Moon soil contains metals from the platinum group like platinum, palladium, osmium or iridium [9]. Moon contains also unique isotopes of helium helium-3, whose lunar resources are evaluated as sufficient to satisfy the energy needs of the Earth for 250 years [10]. Asteroids and other celestial bodies are also being considered as interesting locations for performing mining activities. Mars is considered to be rich in sulphur, zinc-titanium and iron [2]. Recent research shows that Mercury may have large iron and titanium deposits. Jupiter, Saturn, Uranus and Neptune are supposed to contain helium-3 and hydrogen deposits, and their satellites, water that forms the basis for possible colonization of space [2]

Due to the costs and technical difficulties of transportation of natural resources from planets to Earth projects are being made to also perform in space the processing of natural resources. The potential environmental impact of such actions is for today unknown. Other initiatives contain the possibility of bringing the whole asteroids containing natural resources to Earth. Some of them contain huge amounts of coal and water, but also iron, nickel, troilite, olivine, pyroxene, arsenic, selenium, germanium and sulphur [2]. When discussing the natural resources of the outer space it is also worth to mention that a valuable space resource can shortly be the space itself. Space orbits of Earth are becoming more and more intensively used by artificial satellites and can be also treated as a resource. The Bogota Declaration of 1976 shows that attempts are being made to exclude the space orbits from the non-appropriation principle of space law. The situation is worsened by the rising number of space debris which at the number of 750.000 [11] creates an additional challenge for the security of performing space activities [12].

The status of Moon and outer space is currently being regulated by international custom, partly codified by international conventions which were signed almost half a century ago. The Treaty on Principles Governing the Activities of States in the Exploration and Use of Outer Space, including the Moon and Other Celestial Bodies of 1967 (Space Treaty) which has been adopted by the resolution 2222 (XXI) of 
the UN General Assembly is the universally recognised formal source of space law and with 107 ratifications is the most universally binding source of space law. The second important instrument of regulation of access to natural resources of the outer space is the Agreement Governing the Activities of States on the Moon and Other Celestial Bodies of 1979 (Moon Agreement). With only 18 signatories, none of which made by the states which perform in self-launched manned space exploration or has plans to do so [3], it is more considered as a political project showing - in optimistic version - the future of development of space law or - in pessimistic version - dead end of space legislation [30]. Both those legal acts reflect the cold war's bi-polar reality, concentrate on the limitation of military use of the outer space and celestial bodies, and do not reflect the current reality and challenges of the development of space technologies.

The legal status of the outer space is determined by two basic and complementary principles - the principle of freedom of outer space and celestial bodies [13] and the principle of the inadmissibility of their appropriation [13]. The prohibition of appropriation is one of the basic principles of space law [14] and is considered the foundation of this law [15]. For a large part of the doctrine is considered at least the norm of international custom [16], and even the norm is counties [15].

This principle of non-appropriation was explicitly formulated in the resolutions of the General Assembly of the United Nations in 1961 and in 1963 [17]. Space Treaty confirms the existence of this principle. Article II of the Space Treaty prohibits the appropriation of outer space, including the Moon and other celestial bodies. At the time of the creation of this document, the prohibition of appropriation was a warrant of preservation the peaceful nature of the use of space, as well as guaranteed the possibility of using space for all humanity $[18,6]$. The prohibition of appropriation strengthens and guarantees the implementation of the rights resulting from art. I of the Space Treaty guaranteeing free access to all areas of celestial bodies, freedom of research, as well as guaranteeing the special status of outer space as the output of all humanity - res communis omnium [19]. Thus the Space Treaty excluded the possibility of application classical mechanisms of the acquisition of territory to the celestial bodies.

Doubts are being raised if the prohibition of appropriation applies only to states or does this prohibition cover all other entities. Article II of the Space Treaty states that outer space, including the Moon and other celestial bodies, is not subject to national appropriation by claim of sovereignty, by means of use or occupation, or by any other means. It does not mention private entities. Some arguments in favour of the possibility of appropriation of celestial bodies are being given by the Space Treaty itself. Between authentic versions of the text of the Space Treaty, there is a difference - the Chinese version of in art. II of the Space Treaty is different from the versions written in European languages (uses the word "state" instead of "national" so giving some arguments to the supporters of the possibility of private entities appropriation of celestial bodies [20]. The great majority of doctrine, however, recognizes that this prohibition extends also to private entities. They support their arguments by showing the necessary link between private entity and the state needed for executing any form of private possession [21,16], as well as the historical circumstances connected with preparation of the treaty [22] and finally referring to well established international custom [23] and above mentioned principles of international space law [24]. Also, the practice of national courts seems to support the arguments of those who argumentate against the possibility of private appropriation of celestial bodies [25].

The Agreement Governing the Activities of States on the Moon and Other Celestial Bodies of December 18,1979, explicitly resolves the question of the appropriation of the outer space and celestial bodies. In Article 11, it confirms the provisions of art. II Outer Space Treaty, adding in the third paragraph a provision that eliminates the possibility of ownership of the Moon or its part, or its natural resources by state entities, international intergovernmental and non-governmental organizations, national organizations as well as non-governmental entities and natural persons. In this way, the Moon System further clarifies and removes doubts about the activities of private entities in relation to celestial bodies. The fact that the Moon could not be appropriated was additionally confirmed by introducing to the Moon Agreement 
provisions which recognize the Moon and its natural resources as a common heritage of humanity. Those provisions give also some general reflections concerning the use of the natural resources of the moon, and postulate creation of an institutional and procedural framework for use and sharing the common heritage of mankind [29]. Those regulations show deep similarity to the negotiated in the same time period UN Convention on the Law of the Sea (see art. 136 of the UNCLOS Convention), which also uses the institution of the common heritage of humankind. Since the provisions of Article 1 of the Moon Agreement are to be applied to other celestial bodies in the solar system, it can be concluded that the provisions of this Agreement refer to all celestial bodies remaining in the effective range of terrestrial civilization. A certain limitation of the appropriation of appropriation is art. 1 point 3 of the Moon Agreement, which excludes the use of the Agreement in case of meteorites, which independently reached the surface of the Earth - remainings of the meteorites found on the Earth can also be subject of appropriation, to the extent and under the conditions regulated by national law [17].

Analysing the art. I, II and VI of the Outer Space Treaty and art. 11 para. 2 and 3 of the Moon Agreement, the prohibition of appropriation of the areas of outer space and celestial one cannot have the impression of the inadequacy of the existing regulations to the new challenges facing the Earth's civilization. It is difficult to imagine the future colonization of the celestial bodies without guaranteeing the property rights in the area subjected to colonization [30]. This means that there are reasons to expect significant changes in the approach to the legal status of outer space and celestial bodies in the forthcoming decades.

Having established the status of celestial bodies in Space Treaty allows to analyse the status of natural resources in space. The contemporary practice in this field is limited to the problem of possession of samples used for a scientific reason. Based on the principle of freedom scientific exploration of the outer space, there is a consensus as to the legality of performing this type of action [26]. Arguments in favour of the possibility of acquiring ownership of scientific samples are additionally supported by the fact, that scientific exploration of the outer space can be treated as an action undertaken in the interest of the whole mankind. Due to the fact that no mining activity in space has yet been undertaken, no practice exists in the field of commercial exploitation, selling, processing and other [17].

The ownership of natural resources of the outer space creates certain legal problems. This is due to the fact that it not only lacks any practice in this matter but also the Space Treaty does not directly refer to this problem in any of its provision [24]. For some authors, this is enough to argumentate in favour of the possibility of acquisition of natural resources of outer space, by states or other legal or natural persons [27]. For others, the fact that Space Treaty does not distinguish between the celestial bodies and the natural resources situated on them can be interpreted as broadening the principle of non-appropriation also to natural resources of outer space [28].

In the literature, one can find an argument based on the recognition of space as the common province of mankind or as it puts Moon Agreement - of the common heritage of mankind. According to them exploitation of natural resources of outer space is subject to the condition of being able to demonstrate the existence of a guarantee of safeguarding the interest of humankind in the commercial exploitation of natural resources of the outer space. In this context, the doctrine is polarized in their views on how and to which extent such interest should be safeguarded. On the one hand, we have authors pointing to the fact that an important feature of commercial activity is conducting it in the interest of the entrepreneur, state or even groups of states, but not in the interest of all humanity and thus the acquisition of natural resources of the cosmos is an activity contrary to art. I of the Outer Space Treaty [26]. Other authors indicate the possibility of recognizing any commercial activity in space as being in accordance with art. I of the Outer Space Treaty due to the fact that on the occasion of commercial activities there will be an element of providing services to all humanity [3]. Such solutions are referred to in the context of some commercial international space organisations, e.g. the International Mobile Satellite Organization (IMSO). There are 
also arguments that the requirement to safeguard the interest of mankind can be satisfied even by guaranteeing non-discriminatory access to resources and services provided on the basis of resources obtained from space [8]. Finally, at the other extreme, there are opinions that refuse to be normative in the obligation to share the benefits of doing business in space [24].

Regardless of which point of we support - whether we recognize that the resources of the cosmos share the status of celestial bodies and constitute res omnis communes, or can be appropriated, the above-mentioned reflections indicate the possibility of their commercial acquisition, sometimes only limited certain obligations towards the community/humanity. The authors when referring to the status of the natural resources of the outer space sometimes evoke similarities to the freedoms of the full sea [24]. It should be remembered that international law/law of the sea recognises situations in which the ban on the appropriation of maritime space does not diminish the rights to conduct fishing activities. Additional support for this type of argumentation can be found in the position represented by some countries operating in space on a large scale and in the text of the Moon Agreement [24].

The Moon Agreement explicitly refers to the issue of ownership of the natural resources of the outer space. Article 11 paragraph 2 of the Moon Agreement confirms the regulations of the Outer Space Treaty regarding the prohibition of the appropriation of the Moon or celestial bodies by means of all traditional methods of acquiring territory, as well as by all other methods. Its content is clarified by the provisions of art. 11 para. 3 of the Moon Agreement, stipulating that no part of the celestial bodies or their natural resources may be subject to the property of States, national and international organizations, or individuals. At the same time art. 11 para. 1 of the Moon Agreement, states that these resources are the common heritage of mankind. The above-mentioned norms seem to conclusively and unequivocally indicate the ban on commercial use of natural resources of the cosmos. However, it is worth mentioning that the Moon Agreement in art. 11 para. 5 create the possibility to use these resources. The condition is, however, to create a special legal regime that, when it would be possible to obtain its resources, would manage the exploitation of the natural resources of the Moon. One can, therefore, speak of a specific moratorium on conducting commercial activities in the field of acquiring natural resources in space [3]. The moratorium is a relative one - the Moon Agreement does not so much prohibit the commercial use of the natural resources of the Moon and celestial bodies, but de facto allows, conditioning this possibility of states implementing of the obligation of international cooperation in the field of regulation of this form of commercial activity in space.

Understanding the role of international law in managing the natural resources of the Moon and other celestial bodies it seems that this second perspective should be analysed, trying to find some basis for regulatory legal instruments. It seems that a systemic method of interpretation, together with historical methods allows us to reconstruct some elements of the regulatory management regime for the natural resources of the outer space. Arguments based on the concepts of treating the outer space and celestial bodies as it is named in Space Treaty - the common province of mankind, or as it is named in Moon Treaty - the common heritage of mankind play important role in supporting this kind of perspective.

Two concepts, the common province of humanity and the common heritage of mankind which occurred in the Outer Space Treaty and the Moon Agreement shape the relationship of states, collective entities and individuals to celestial bodies and cosmic resources. Understanding the designates of these concepts in the context of the use of the natural resources of outer space and celestial bodies is the key to finding the method of sharing the resources of the outer space. Unfortunately, the norms of international law are silent both when it comes to the attempt to define what the common province and common heritage are.

Mankind, as a designatum - subject of common heritage concept, seems to be a community of people to whom specific legal or ethical duties can be assigned, and sometimes this collective being can be considered as a subject of rights [31]. Its characteristic feature is the ability to include into this category both the contemporary generation and generations of past and future [32-34]. Accepting this way of 
reasoning, the common achievement of humanity (province of all mankind) will mean a form of the collective authority of the human race in relation to the celestial bodies and the moon [3]. The character of this authority may be legal, then it will necessarily exclude any forms of implementation of sovereignty by other entities (eg. states) over this area, or purely moral, idealistic - without the abovementioned consequences for the issue of ownership or sovereignty [35].

The basic obligations stemming from treating outer space as a common province of mankind is the already mentioned ban on appropriation of the outer space and its resources as well as the obligation to refrain from making use of space that would contradict the legitimate and protected by international law interest of other members of international community or which would pose a danger to their security and sovereignty [13].

The concept of the common heritage of mankind, introduced to the space law by the Moon Agreement, seems to supplement or even replace the concept of the common province of mankind [3]. The ability of treating the concept of the common heritage of mankind as a separate institution may be supported by the existence slightly different designate - in the case of the Outer Space Treaty, it is the entire outer space, while the Moon Agreement mentions Moon and celestial bodies. Also, the huge disparity in a number of ratifications between the Outer Space Treaty and Moon Agreement seems to confirm the difference between those two concepts. It is especially important in the situation in which the main difference between those two international legal acts was the introduction to the Moon Agreement of the concept of common heritage of mankind and attempts to make this concept legally operative[36]

The basic problem with giving the concept of the common heritage of humanity as having the legal significance is the fact that accepting it would also mean the elimination of the possibility of states to execute their sovereign rights. When doing this some alternative management mechanism to protect the interests of states and/or individuals has to be introduced - the preferably a new international legal regime of outer space [37]. The common heritage of mankind concept despite the fact of being recognised as an international legal concept is not fully shaped and its legal content is subject to the existence of a comprehensive system of rights and duties which lacks in case of the existence of this concept in international space law. International seabed exploration and exploitation regime can be an example of a system in which the common heritage of mankind was attributed with more or less specified rights and duties as well as institutional and procedural infrastructure. Observing its functioning in relation to the seabed, Arctic, or outer space, one can recognize that the legal operativeness of the common heritage of mankind concept is strongly dependent on to what extent the international space law is able to create conditions for the creation and enforcement of a special legal regime that would balance the interest of humanity as inter and intragenerational community with the contemporary interest of a single state, or even an individual [37]. For this reason there must be made a distinction between the institution known for ages of areas considered as res extra commercium, or res communis - the area on which humanity is dependent and which should be used for the benefit of all humanity[38] (Articles I and II of the Outer Space Treaty indicates the existence of a common interest of states in the research and exploitation of space)[35], and terra comunis humanitatis, an area fulfilling all the above-mentioned criteria, but additionally simultaneously managed by the whole mankind, as it is in the concept of common heritage of mankind[3]. Putting it differently - both the concept of the common province of mankind and the common heritage of mankind, accept the phenomenon described as tragedy of commons [39] as the basic goal and condition of their effectiveness - the situation in which shared resources are abused by specific individuals in order to maximize their benefits at the expense of community benefits, in this case, humanity [40,2]. They differ however in the solutions to this problem.

The concept of a common heritage of mankind is connected with the creation of a legal regime that guarantees: prohibition on the appropriation and implementation of sovereign rights by states; transfer of rights to the natural resources to the mankind as a whole; the use of the area being considered as a 
common heritage for peaceful purposes only; sharing of natural resources which exist in the area covered by the concept of the common heritage of mankind with particular regard to the interests of developing countries; management of the area by means of establishing a specific international legal regime; some authors distinguish as a separate element the requirement of protection of the common heritage in the interests of future generations [41].

The joint introduction of the above mentioned elements makes it possible to implement the concept of a common human heritage. The possibility of imposition of some from the above-mentioned obligations related to the use of terra communis humanitatis has become the reason why the Moon Agreement is currently not playing any important role in the regulation of space activity [42]. It plays some role as a document that does not bind most space powers but indicates the possible direction of future development of space law. A more pessimistic perspective may consider Moon Agreement as a kind of "dead end". The commonly recognised as reflecting the concept of common heritage of mankind, the regime of seabed resources agreed in UNCLOS in 1982 had to be "softened", through the 1994 implementation agreement [43]. The changes were connected with the greater implementation of market mechanisms in the field of technology transfer, decision-making and exploitation of natural resources, ensuring better protection of investors' rights [43]. After their introduction governance mechanisms with respect to the resources of the seabed were able to be accepted by some of the biggest players (however still not by the USA) [43]. Also in the case of the regime established by the Moon Agreement the concept of a common human heritage faced opposition from both the USSR and the US and some other high developed countries. The only alternative to the current state of functioning of the concept of the common heritage of humanity as a concept that is sometimes judged as deprived of realism and chances of practical application in the field of outer space resources management [44] is its deep reform similar to this which was made with introduction of 1994 implementation agreement to the deep seabed mining regime. Such stipulation seems to remain largely in line with the assumptions of art. 11 para. 5-8 of the Moon Agreement and the widely represented in the doctrine belief about the need to adopt a new instrument regulating the exploitation of natural resources of the cosmic space [41]. The basic goals of this regime should be: insurance that the natural resources of outer space will be used in most efficient and sustainable way; rational management of those resources; development of capabilities of use of natural resources of the outer space; a fair distribution between all countries of the benefits coming from the resource exploitation; protection of the development capabilities of future generations by using the concept of sustainable development [13].

Conclusion. Being informed about new technical solutions and discoveries connected with the forthcoming perspective of utilization of space resources one wish that the model of exploration of natural resources of the outer space should differ from the unsustainable and often unfair models in which the mining activities were undertaken on Earth. The first come first served model of the acquisition of Earth's natural resources which can be dated back to $17^{\text {th }}$ century and East India Company, repeated later during the industrial revolution and in some form practised even today should not be repeated for Earth's and Space's sake. Meanwhile, we face the reluctance of international society to take advantage of this window of opportunity and regulate space mining before such activities will start. International law does not function in a vacuum. In case of lack of international agreement in the field of space, mining countries will start their own regulatory initiatives creating opportunities for companies under their jurisdiction to become pioneers of this new and undoubtfully profitable area. The US Space Resource Exploration and Utilization Act of 2015 leaves no doubt about the recognition of the property rights over natural resources of the outer space acquired by US citizens (see $\S 51303$ of US Space Resource Exploration and Utilization Act). Similar regulations are trying to introduce other countries from Luxemburg to United Arab Emirates [45]. What we are facing in this field is a certain form of regulatory competition which should be framed in some form of international legal regime. Revocation to general principles of law can be ineffective in a situation 
of lack of political will to cooperate inequitable sharing the outer space.

Table 1 - Exploitation of outer space natural resources under Outer Space Treaty and Moon Agreement

\begin{tabular}{|c|c|c|}
\hline & Outer Space Treaty & Moon Agreement \\
\hline Appropriation of outer space & no & no \\
\hline Appropriation of celestial bodies & no & no \\
\hline $\begin{array}{c}\text { Right to collect samples (for scientific } \\
\text { purposes) }\end{array}$ & $\begin{array}{l}\text { freedom of scientific } \\
\text { investigation }\end{array}$ & $\begin{array}{l}\text { freedom of scientific investigation, } \\
\text { right to detain samples }\end{array}$ \\
\hline Ownership of natural resources & no & $\begin{array}{c}\text { no (yes) } \\
\text { (until the international managerial } \\
\text { regime is created) }\end{array}$ \\
\hline Management model of common areas & Province of mankind & Common heritage of mankind \\
\hline Number of ratifications/accessions & 107 & 18 \\
\hline
\end{tabular}

Recourses: developed by the author on the bases of the official United Nations webpage www.treaties.un.org

1. J. Gilas, Sprawiedliwość międzynarodowa gospodarcza, Toruń 1991,

2. M. Nyka Instrumenty ograniczania wpływu handlu na środowisko. Studium z prawa międzynarodowego. Warszawa 2018

3. R. Lee Law and Regulation of Commercial Mining of Minerals in Outer Space. Dordrecht New York, 2012

4. D. Pyć Prawo oceanu światowego. Gdańsk 2011

5. B. Boutros-Ghali International Cooperation in Space Activities for Enhancing Security in Post-Cold War Era UN Doc. $\mathrm{A} / 48 / 221$,

6. F. Tronchetti The Exploitation of Natural Resources of the Moon and other Celestial Bodies. A Proposal for a Legal Regime. Leiden/Boston 2009;

7. L. Viikari The Envronmental Element in Space Law: Assessing the Present and Charting the Future. Leiden/Boston 2008

8. N. Harn Commercial Mining of Cellestial Bodies: A legal Roadmap. The Georgetown International Environmental Law Review. Vol. 27 (2015),

9. B. Cooper, D. Schrunk, G. Sharpe, M. Thungavelu (ed.) The Moon: Resources, Future Development, and Settlement, Berlin Springer and Praxis, 2008,

10. C. Neal The Moon 35 years after Apollo: What's Left to Learn. Chemie der Erde vol. 69 (2009)

11. https://www.esa.int/Our_Activities/Operations/Space_Debris/About_space_debris

12. J. Pearson, E. Levin, J. Carroll Enhancing Space Elevator Safety by Active Debris Removal. CLIMB vol. 1, no. 1 (2011),

A. Górbiel Międzynarodowe prawo kosmiczne. Warszawa 1985

13. Z. Galicki Status prawny kosmosu. [in:] A. Wasilkowski (ed.) Działalność kosmiczna w świetle prawa międzynarodowego. Wrocław, Warszawa, Kraków 1991,

14. F. Tronchetti The Non-appropriation Principle Under Attack: Using Article II of the Outer Space Traty in it's Defence. International Astronautical Federation Paper IAC-07-E6.5.13 (2007),

15. R. Lee Article II of the Outer Space Treaty: Prohibition of State Sovereignty, Private Property Rights or Both?. Australian Journal of International Law vol. 11(2004),

16. Z. Galicki Status prawny kosmosu. [in:] A. Wasilkowski (ed.) Działalność kosmiczna w świetle prawa międzynarodowego. Wrocław, Warszawa, Kraków 1991,

17. F. van der Dunk International space law. [in:] F. van der Dunk, F. Tronchetti. (ed.) Handbook of space law Edward Elgar 2015 ,

18. M. Smirnoff Legal Studies on Celestial Bodies. Journal of Air Law \& Commerce vol. 28 (1961-1962)

19. R. Lee Article Il of the Outer Space Treaty: Prohibition of State Souvereignity, Private Property Rights, or Both?. Australian Journal of International Law vol. 11 (2004),

20. P. Sters, L. Tennen Privateering and Profitering on the Moon and Other Celestial Bodies: Debunking the Myth of Property Rights in Space. Proceedings of the Forty-fifth Colloquium on the Law of Outer Space (2003),

21. V. Pop Appropriation in Outer Space: The Relationship Between Land and Ownership and Souvereginity on the Clelestial Bodies. Space Policy vol. 16 (2000),

22. L. Tennen Second Commentary on Emerging System of Property Rights in Outer Space Proceedings of the United Nations/Republic of Korea Workshops on Space Law (2003)

23. F. Tronchetti Legal aspects of space resource utilization [in:] F. van Dunk, F. Tronchetti (ed.) Handbook of space law Edward Elgar 2015

24. Gregor Nimitz vs. The United States of America et. al. 2003 WL 24268455 (D.Nev.) 6 Nov. 2003.

25. M. Listner The Ownership and Exploitation of Outer Space: A Look at Foundational Law and Future Challenges to Current Claims. Regent Journal of International Law vol. 1 (2003), 
26. B. Cheng Le Traité de 1967 sur l'espace. Journal du droit international no 3 (1968),

27. S. Gorove Limitations on the Principles of Freedom of Exploration and Use in Outer Space: Benefits and Intersts. [in:] Proceedings of the Thirteenth Colloquium on the Law of Outer Space (1971),

28. F. Lyall, P. Larsen Space Law. A Treatise. Ashgate/Burlington 2009, (2015)

29. W. Erlank Rethinking Terra Nullius and Property Law in Space. [w:] Potchefstroom Electronic Law Journal, Vol. 18, No. 7,

30. E. Fasan The Meaning of the Term Mankind in Space Legal Language Journal of Space Law vol. 2 (1974),

31. S. Williams The Law of Outer Space and Natural Resources. International Law \& Comparative Law Quertarly vol. 36 (1987),

32. S. Grove The Concept of "Common Heritage of Mankind": A Political, Moral or Legal Innovation? San Diego Law Review vol. 9 (1972),

33. M. Nyka Future Generations Rights to Natural Resources: The Post Rio 20+ Perspective [w:] Enacting Environmental Justice through Global Citizenship M. Nyka, E. Schneider (ed.) Oxford 2014

34. D. Tan Towards a New Regime for the Protection of Outer Space the "Province of All Mankind". Yale Journal of International Law vol. 25(2000),

35. J. Gabrynowicz The "Province” and „Heritage” of Mankind Reconsidered: A New Beginning. he Second Conference on Lunar Bases and Space Activities of the 21st Century, Proceedings from a conference held in Houston, TX, April 5-7, 1988. Edited by W. W. Mendell, NASA Conference Publication 3166, 1992,

36. T. Adams The Outer Space Treaty: An Interpretation in Light of the No-Souvereignity Provision. Harvard International Law Journal vol. 9 no. 1 (1968)

37. M. Lachs The Law of Outer Space: An Experience in Contemporary Law-Making Laiden 1972

38. J. Brunnee Common Areas, Heritage, Concern. [in:] D. Bodansky, J. Brunne, E. Hey (ed.) Oxford Handbook of International Environmental Law Oxfrod 2007,

39. G. Hardin The Tragedy of the Commons, Science no . 162 (1968),

40. R. Wolfrum The Principle of the Common Heritage of Mankind. Zeitschrift für ausländisches öffentliches Recht und Völkerrecht vol. 43 (1983),

41. S. Mirzaee Outer Space and Common Heritage of Mankind: Challenges and Solutions. RUDN Journal of Law t. 21 , no 1.

42. J. Noyes The Common Heritage of Mankind: Past, Present and Future. Denver Journal of International Law and Policy vol. 40 no $1-3$

43. S. Bhat The Concept of Common Heritage of Mankind in the Governance of the Moon - An Insight into Article 11 of the Moon Agreement. Legal Opus vol. 1 (2007),

44. S. Freeland Common heritage, not common law: How international law will regulate proposals to exploit space resources. Questions of International Law vol. 35 (2017)

М. Ника, д.Ю.н. Університет Гданська (Гданськ, Польща)

Правові передумови управління природними ресурсами Місяця та інших небесних тіл

Основною метою даного дослідження $є$ аналіз діючої міжнародної правової бази гірничо-видобувної діяльності у космічному просторі. Використання та обмін природними ресурсами космічного просторує актуальною проблемою для міжнародної нормативно-правової системи. Існуючі законодавчі акти, що регулюють використання космічного простору, вже застаріли, а деякі з них мають другорядну роль внаслідок ратифрікації інших законів. Автором наголошено на необхідності адаптації правил використання та справедливого розподілу вигід від використання космічних природних ресурсів у відповідності до загальних законодавчих норм та з урахуванням специфіки управління космічним простором, а також синхронізації їх з міжнародними угодами. Автором зазначається, що використання принципів «не привласнення» та «свободи проведення наукових досліджень космічного простору» обумовлюють обмеження повноцінного розвитку комерційної діяльності у космосі. При цьому недосконалість правової системи, неоднозначне трактування міжнародноправових норм створюють підстави для появи низки дискусій щодо характеру та специфріки регулювання процесу розробки космічних природних надр. 3 метою аналізу поточного статусу небесних тіл і космічного простору з правової точки зору автором розглядається дві концепиії: 1) природні ресурси космосу як спільна компетенція (сфере діяльності) суспільства; 2) природні ресурси космосу як спільна спадщина людства. Автор зауважує, нормативні наслідки використання цих двох концепцій є непередбачуваними. У дослідженні наголошено, що перша концепція майже не застосовується в міжнародному праві, а друга є більш поширенішою, тому може розглядатися як основа для розробки нормативного регулювання, відповідних процедур та інституційної підтримки. У статті аналізуються потенційні умови, за яких розробка космічних природних надр може слугувати на користь людства. Окрім цього автор досліджує дієвість існуючої системи управління космосом (включаючи небесні тіла та природні ресурси, розташовані на них) та ї здатність просувати принципи та иінності міжнародного космічного права. У роботі систематизовано перспективи розвитку міжнародного космічного права щодо регулювання розробки космічних природних надр. На основі результатів аналізу правового регулювання видобутку глибоководних природних ресурсів автором запропоновано заходи щодо розвитку та адаптації міжнародного космічного права.

Ключові слова: Місяць, управління, норми, закон, ресурси. 